\title{
PENGEMBANGAN DIGIBOOK DALAM PEMBELAJARAN TEMATIK TEMA DAERAH TEMPAT TINGGALKU UNTUK SEKOLAH DASAR
}

\author{
Erna Yayuk, Kuncahyono \\ Program Studi PGSD FKIP Universitas Muhammadiyah Malang \\ Email: ernayayuk17@gmail.com,
}

Naskah diterima : 7 Agustus 2017, direvisi : 31 Agustus 2017, disetujui : 5 September 2017

\begin{abstract}
Abstrak
Era Globalisasi menuntut guru untuk selalu berinovasi dalam melakukan proses pembelajaran. Inovasi bisa dilakukan dengan berbagai hal salah satunya dengan pengembangan bahan ajar. Penelitian ini bertujuan untuk mengembangakan Digibook (buku digital) yang sesuai dengan kebutuhan lapang untuk meningkatkan kompetensi guru SD dalam mengelola Pembelajaran Tematik. Target khusus yang ingin dicapai adalah terdokumentasikannya : inventarisasi, klasifikasi, dan kategori atas persepsi guru di sekolah dasar tentang kemanfaatan digibook dalam mengelola pembelajaran SD yang dianalisis secara multidisiplin untuk ditarik asumsi, pendekatan, paradigma, konsep dan teori. Hal ini penting dilakukan agar dapat dijadikan pijakan dalam pengembangan Digibook. Studi ini dikembangkan melalui penelitian 4D (Four-D) dengan pendekatan kualitatif agar secara tepat mampu menangkap makna dari realitas guru dalam mengajar, Metode yang digunakan adalah deskriptif. Data diperoleh melalui hasil observasi, dokumentasi, wawancara, foto lokasi dan perilaku, dan hasil isian angket. Data dianalisis dengan model interaktif Hubberman yang meliputi pengumpulan data, reduksi data, analisis data dan verifikasi data. Selanjutnya dihasilkan penelitian dengan laporan naratif dan produk berupa Digibook. Hasil penelitian menunjukkan bahwa pengembangan digital buku (Digibook) sangat sesuai kebutuhan anak pada tingkat SD dan dalam penggunaannnya sangat efektif dalam membantu siswa memahami materi pembelajaran mereka merasa senang serta dengan dikembangkannya digibook memudahkan guru dalam melaksanakan pembelajaran berbasis ICT .
\end{abstract}

Kata Kunci: Digibook, Pembelajaran Tematik, Tema Daerah

Pengutipan: Yayuk, Erna dan Kuncahyono. (2017). Pengembangan Digibook dalam Pembelajaran Tematik. Tema Daerah Tempat Tinggalku untuk Sekolah Dasar. JMIE: Journal of Madrasah Ibtidaiyah Education, 1(2), 2017, 155-171. jmie.v1i2.36. 


\section{PENDAHULUAN}

Berbagai hasil studi dan pengamatan terhadap mutu pendidikan pada berbagai negara menunjukkan bahwa secara makro mutu pendidikan di Indonesia masih rendah, dan bahkan secara nilai rata-rata di bawah peringkat negara ASEAN lainnya. Walaupun demikian, secara individual ada beberapa diantara peserta didik mampu menunjukkan prestasinya di lomba-lomba bertaraf internasional, seperti pada Olimpiade Fisika. Untuk mewujudkan masyarakat yang cerdas, diperlukan proses pendidikan yang bermutu dan kunci utama dalam peningkatan mutu pendidikan adalah mutu guru. Proses pendidikan dalam masyarakat abad 21 adalah suatu interaksi antara guru dengan peserta didik sesuai dengan kemajuan ilmu pengetahuan dan teknologi dalam masyarakat yang demokratis dan terbuka (Depdikans, 2001).

Masyarakat yang demikian menuntut adanya pelayanan yang profesional dari para pelakunya dan guru adalah seorang profesional dalam masyarakat seperti itu. Dengan kata lain, guru dituntut untuk berperlaku dan memiliki karakteristik profesional oleh karena tuntutan dan sifat pekerjaanya dan bersaing dengan profesi-profesi lainnya. Tantangan guru pada masyarakat abad 21 adalah bagaimana menjadi seorang guru yang profesional untuk membangun masyarakat yang mandiri, memiliki ilmu pengetahuan dan teknologi, berprestasi, saling menghormati atas dasar kemampuan individual, menjunjung tinggi rasa kebersamaan, dan mematuhi nilai-nilai hukum yang berlaku dan disepakati bersama .

Di era globalisasi, guru sangat dituntut meningkatkan profesionalitasnya sebagai pengajar dan pendidik. Disamping profesionalitas, guru juga harus menghadapi beberapa kata kunci dunia pendidikan yaitu, kompetisi, transparansi, efisiensi, dan kualitas tinggi. Dari segi sosial, masayarakat global akan menjadi sangat peka dan peduli terhadap masalahmasalah demokrasi, hak asasi manusia, dan isu lingkungan hidup.Kendala tersebut harus dihadapi guru dengan sangat arif. Maka tidak heran jika pemerintah mengadakan sertifikasi guru, agar profesionalitas guru terwujud. Perhatian pemerintah memberi solusi terhadap persoalan dunia pendidikan khsusunya guru, di implementasikannya dengan sertifikasai guru dan meningkatkan kesejahteraanya dengan peningkatan tunjangan pendidikan. Dengan demikian, kulaitias mutu pendidikan harus sangat diperhatikan bagi para guru untuk menyelamatkan profesinya. Menanggapi persoalan tersebut, dalam peningkatan kualiatas pengajaran, guru harus bisa mengembangkan tiga intelejensi dasar siswa. Yaitu, intelektual, emosional dan moral. Tiga unsur itu harus ditanamkan pada diri murid sekuatkuatnya agar terpatri didalam dirinya.

Selain itu, sebagai seorang profesional, guru seharusnya memiliki kapasitas yang memadai untuk melakukan tugas membimbing, membina, dan mengarahkan peserta didik dalam menumbuhkan semangat keunggulan, motivasi belajar, dan memiliki kepribadian serta budi pekerti luhur yang sesuai dengan budaya bangsa Indonesia (Mulyana:2007). Namun demikian, kita semua mengetahui bahwa begitu banyak tantangan yang dihadapi oleh seorang guru dalam upaya untuk melaksanakan tugasnya secara profesional di masa datang, yaitu dalam menghadapi masyarakat abad 21. Tugas yang sangat mulia yang diemban oleh seorang guru agar dilaksanakan dengan penuh keikhlasan dan mengharuskan seorang guru mengembangkan pengalaman dan pengetahuan di era globalisasi seperti sekarang ini, demi meningkatnya kualitas ilmu pengetahuan yang diterima oleh peserta didik. Guru dituntut untuk selalu mengikuti perkembangan zaman, baik dari segi ilmu pengetahuan maupun dari segi teknologi. 
Gambaran kondisi diatas menyatakan bahwa guru sebagai masyarakat sekolah harus melek teknologi. Hal ini merupakan salah satu karakteristik dari gambaran abad 21. Pada Abad 21 ini ditandai hadirnya berbagai jenis komputer dan internet di dunia pendidikan yang memberikan banyak tawaran dan pilihan dalam rangka menunjang proses pembelajaran. Proses pembelajaran ini akan berjalan dengan efektif dan menyenangkan manakala guru mampu untuk berinovasi dalam pembelajarannya. Salah satunya yaitu ditunjukkan dengan kemampuan guru dalam pengembangan sumber pembelajaran berbasis multimedia.

Salah satu sumber belajar yang bisa dikemas dalam bentuk multimedia adalah buku. Pengembangan ini bisa dilakukan dalam bentuk Digibook. Digibook sendiri merupakan buku digital yang mempunyai kecepatan dalam mendapatkan informasi, memiliki fasilitas yang dapat membuat belajar lebih menarik, visual, dan interaktif. Guru sebagai ujung tombak pendidikan harus siap menghadapi tantangan ini. Sebagian besar guru merasa ragu dan tidak akrab dengan teknologi informasi semacam internet. Bahkan ada yang menganggap hanya mengganggu kosentrasi belajar siswanya. Siswa lebih dahulu menguasai teknologi informasi ketimbang gurunya. Dan yang dilakukan siswa di warnet biasanya aktifitas bermain game online.

Berdasarkan paparan di atas, terlihat adanya gambaran tentang apa dan bagaimana karakteristik masyarakat pada abad 21 dan apa peran pendidikan pada masa yang akan datang serta tantangan bagi seorang guru untuk menyikapinya. Pendidikan pada dasarnya tidak terlepas dari peran penting guru sebagai tulang punggung dan penopang utama dalam proses penyelenggaraan pendidikan (Djaman, 2003). Oleh karena itu, guru era baru di tuntut untuk bisa berinovasi salah satunya yaitu dengan pengembangan DIGIBOOK. Keuntungan menggunakan digibook berbasis multimedia ini dalam pembelajaran adalah membuat proses pembelajaran lebih menarik, interaktif dan menyenangkan kepada peserta didik. Dengan digibook tersebut maka video pembelajaran dapat terintegrasi di dalam digibook, menjadi satu kesatuan yang tidak terpisahkan. Tampilan dari digibook ini juga sangat bervariasi dan menarik tergantung bagaimana kita mensettingnya. Penggunaan digibook ini bisa menjadi terobosan baru dalam mengimplementasikan proses pembelajaran dengan TIK yang berbasis multimedia, selain dengan powerpoint dan flash.

Untuk itulah perlu dikaji secara mendalam bentuk Digibook pada Pembelajaran Tematik yang bagaimanakah yang sesuai dengan kebutuhan lapang untuk meningkatkan kompetensi guru SD dalam mengelola pembelajaran di sekolah dasar. Hal ini sesuai dengan RENSTRA Penelitian UMM tahun 2016-2020, yang salah satu isu strategis bidang pendidikan adalah peningkatan kompetensi dan profesionalisme Guru. Di samping itu hal ini akan sangat bermanfaat bagi Program Studi PGSD yang Universitas Muhammadiyah Malang menawarkan keunggulan, yaitu " menghasilkan lulusan yang mampu mengelola pembelajaran di sekolah dasar dengan pemanfaatkan teknologi, dalam upaya meningkatkan kompetensi guru SD dengan menciptakan pembelajaran yang nyaman, menyenangkan dan edukatif. 


\section{KAJIAN PUSTAKA}

\subsection{Gambaran Guru di Era Global}

Untuk memberikan gambaran tentang tantangan guru yang prfeesional di masa depan, perlu melihat karakteristik masyarakat di era globalisasi dikaitkan dengan peran pendidikan. Menurut Tilaar (dalam Mulyana:2007), setidaknya terdapat tiga karakteristik masyarakat di abad 21, yaitu: (1)masyarakat teknologi;(2)masyarakat terbuka;(3) masyarakat madani.

\section{a. Masyarakat Teknologi}

Masyarakat teknologi yang dimaksud adalah suatu masyarakat yang telah melek teknologi dan menggunakan berbagai aplikasi teknologi, sehingga dapat mengubah cara berfikir dan bertindak bahkan mengubah bentuk dan pola hidup manusia yang sama sekali berlainan dengan kehidupan sebelumnya. Kemajuan teknologi kkomunikasi telah mebuat jarak dan waktu semakin pendek dan cepat, sehingga seolah-olah dunia menjadi satu tanpa ada sekat yang membatasi bangsa-bangsa, negara-negara, bahkan pribadi-pribadi. Kemajuan teknologi dapat memajukan kehidupan manusia, tetapi dapat pula menghancurkan kebudayaan umat manusia. Untukitu, dalam mengiringi kemajuan teknologi tersebut diperlukan upaya penghayatan, di samping penguasaan teknologi itu sendiri.

Dalam maysarakat seperti itu, peran pendidikan dan guru sangat penting dan strategis, terutama dalam memberikan bimbingan, dorongan, semangat, dan fasilitas kepada masyarakat dan peserta didik untukmemperoleh ilmu pengetahuan dan keterampilan menggunakan teknologi. Selain itu, tidak kalah pentingnya adalah peran pendidikan dalam memberikan arahan dan bimbingan agar penguasaana teknologi tidak menjadi bumerang bagi masyarakat, yang disebabkan kurangnya penghayatan terhadap etika. Pendidikan dan guru dapat menumbuhkan pemahaman etika yang benar, agar kehidupan manusia tidak terancam oleh karena kemajuan teknologi itu sendiri. Manakala pendidikan mengisyaratkan adanya keharusan peserta didik untuk menguasai teknologi, maka tentu tidak kalah pentingnya peran guru itu sendiri untuk lebih dulu menguasai ilmu pengetahuan dan teknologi agar dapat memberikan pengetahuan dan keterampilan teknologi terkini kepada peserta didik. Penguasaan terhadap IPTEK memang harus diiringi dengan pemahaman etika yang benar agar moral bangsa kita tetap terjaga dengan baik sehingga tidak terjadi lagi perlanggaran-pelanggaran etika yang terkait dengan pemanfaatan teknologi pada abad 21.

Karena IPTEK adalah sesuatu yang sangat cepat dalam perkembangannya, banyak perubahan-perubahan yang muncul ketika ilmu pengetahuan dan teknologi berada di tengah-tengah masyarakat seperti sekarang ini. Banyak orang-orang yang semakin pintar membuat sesuatu yang baru sehingga dapat mengalahkan apa-apa yang muncul pada sebelum-sebelumnya.

\section{b. Masyarakat Terbuka}

Lahirnya teknologi komunikasi yang demikian maju, membuat dunia menjadi satu seolah tanpa sekat, sehingga komunikasi antar pribadi menjadi makin dekat dan hampir tanpa hambatan, yang pada akhirnya melahirkan masyarakat terbuka. Dalam masyarakat 
terbuka, antara bangsa satu dengan bangsa lain dapat saling mempengaruhi dalam berbagai hal, termasuk mempengaruhi budaya bangsa lain. Hal itu mengancam kehiudpan masyarakat lain oleh karena adanya kemungkinan penguasaan atau dominasi oleh mereka yang lebih kuat, yang berprestasi dan yang memilikimodal terhadap masyarakat yang lemah, tidak berdaya dan miskin. Untuk itu, dalam masyarakat terbuka diperlukan manusia yang mampu mengembangkan kapasitasnya agar menjadi manusia dan bangsa yang kuat, ulet, kreatif, disiplin, dan berprestasi, sehingga tidak menjadi korban dan tertindas oleh zaman yang penuh dengan persaingan.

Setiap manusia mempunyai kesempatan yang tidak terbatas untuk belajar dan mengembangkan diri atau bahkan melalui kapasitasnya memberikan sumbangan kepada masyarakat lainnya, baik masyarakat lokal maupun masyarakat dunia. Tetapi sebaliknya, bila kapasitas sumber daya manusia itu tidak dikembangkan, maka akan menjadi manusia dan masyarakat yang lemah dan tidak berdaya, yang pada akhirnya akan menjadi boneka atau korban bagi mereka yang lebihkuat, lebih kreatif dan memiliki ilmu pengetahuan dan teknologi. Peran pendidikan sangatlah penting untuk meningkatkan harkat dan martabat suatu masyarakat dan bangsa, agar tidak menjadi bangsa pelayan yang dapat diperintah bangsa lain. Sangat ironis bila bangsa kita yang besar ini tidak mampu bersaing dengan bangsa2 lain, yang hanya mengandalkan kuantitas tanpa kualitas, yang mngandalkan banyak sikil ketimbang skill ..tentu sudah saatnya bagi bangsa ini untuk mengirimkan tenaga2 ahli/profesional ke luar negeri dan bukan mengirimkan PRT/tenaga kasar/buruh ke luar negeri yang hanya bisa menjadi budak bagi bangsa-bangsa lain.

\section{c. Masyarakat Madani.}

Masyarakat madani merupakan wujud dari suatu masyarakat terbuka, di mana setiap individu mempunyai kesempatan yang sama untuk memperoleh ilmu pengetahuan dan keterampilan menggunakan teknologi, berkarya, berprestasi dan memberikan sesuatu sesuai dengan kapasitasnya. Masyarakat madani tumbuh berkembang dalam suatu masyarakat yang saling hormat-menghormati, bukan atas dasar asal-usul atau keturunan, tetapi berdasarkan pada kemampuan individual, memiliki toleransi dan tanggungjawab terhadap kehiudpan pribadi maupun masyrakatnya, serta menjunjung tinggi rasa kebersamaan untuk mencapai kesejahteraan bersama.

Masyarakat madani adalah masyarakat yang saling menghargai satu dengan yang lain, yang mengakui akan hak-hak asasi manusia, yang menghormati prestasi individual, dan masyarakat yang turut bertanggung jawab terhadap kelangsungan hidup dari masyarakatnya, termasuk nilai-nilai etis yang diyakini kebenarannya.

Masyarakat madani tumbuh dan berkembang bukan dengan sendirinya dan bukan tanpa upaya terencana, tetapi masyarakat yang dibangun melalui pendidikan. Kunci terwujudnya masyarakat madani adalah pendidikan, karena melalui pendidikan dapat dibangun sumberdaya yang berkualitas dengna kepribadian yang sesuai dengan budaya serta kesadaran individu hidup berdampingna untuk mencapai tujuan bersama.

Globalisasi dinilai berpengaruh terhadap hamper semua aspek yang ada di masyarakat, termasuk aspek budaya. Globalisasi sebagai sebuah gejala tersebarnya nilai-nilai dan budaya tertentu ke seluruh dunia, sehingga menjadi budaya dunia (world culture), telah terlihat sejak lama. Cikal bakal dari persebaran budaya dunia ini dapat ditelusuri dari perjalanan para 
penjelajah Eropa Barat ke berbagai tempat di dunia ini. Namun, perkembangan globalisasi kebudayaan secara intensif terjadi pada awal abad ke-20 dengan berkembangnya teknologi komunikasi. Kontak melalui media menggantikan kontak fisik sebagai sarana utama komunikasi antar bangsa. Setidaknya semenjak awal tahun 2003 teknologi dan informasi (IT) sebagai ikon globalisasi berkembang sangat pesat (tidak ketinggalan) di Indonesia hingga membuat pemerintah jadi kerepotan dan mengambil sikap reaktif mengubah kurikulum pendidikan untuk disesuaikan dengan tuntutan globalisasi.

Secara garis besar globalisasi berimplikasi pada profesionalitas guru yaitu Guru dalam Perspektif Globalisasi. Guru di era global adalah guru dengan profesionalitas tinggi mempunyai tugas yang tidak akan semakin ringan, maka harus berkualitas. Wardiman Djojonegoro dalam konteks ini pernah menyatakan dalam makalahnya,9 bahwa bangsa kita menyiapkan diri untuk memiliki sumber daya manusia (SDM) yang berkualitas. Ciri SDM yang berkualitas tersebut adalah memiliki kemampuan dalam menguasai keahlian dalam suatu bidang yang berkaitan dengan iptek, mampu bekerja secara profesional dengan orientasi mutu dan keunggulan, dan dapat menghasilkan karya-karya unggul yang mampu bersaing secara global sebagai hasil dari keahlian dan profesionalitasnya. Sebagai tenaga pendidikan, guru professional tidak lepas dari pencitraan yang diberikan dari orang lain. Dalam kehidupan bermasyarakat di era ini guru di satu sisi diharapkan lebih bermoral dan berakhlak daripada masyarakat umum, tetapi di sisi lain muncul problem baru sebagai tantangan manakala guru tidak memiliki kemampuan materi untuk memiliki segala akses dan jaringan informasi sepeti TV, buku-buku, majalah, Koran, dan internet, karena guru memiliki gaji dan tunjangan yang jauh dari cukup untuk meningkatkan profesinya sekaligus memperkaya informasi mengenai perkembangan pengetahuan dan berbagai dinamika kehidupan glibal, sehingga sangat sulit dibayangkan guru dapat tampil lebih professional dan memiliki tanggungjawab moral profesi sebagai konsekuensi etisnya di era global ini. Pemerintah pun berupaya mengatasi problem tersebut dalam rangka meningkatkan profesionalitas guru dengan mengadakan sertifikasi guru. Perhatian pemerintah tersebut diharapkan dapat memberi solusi terhadap persoalan dunia pendidikan khsusunya guru, diimplementasikannya dengan sertifikasai guru dan meningkatkan kesejahteraanya. Dengan demikian, kualitas mutu pendidikan harus sangat diperhatikan bagi para guru untuk menyelamatkan profesinya, lebih-lebih di era global seperti sekarang.

\subsection{Digibook}

Digitalbooks (Digibook) merupakan sebuah publikasi yang terdiri dari teks, image, video, dan suara yang dikemas dalam bentuk digital yang dapat dioperasikan dengan PC dan produk ITC lain. Dengan kata lain Digibook adalah buku digital yang mempunyai kecepatan dalam mendapatkan informasi, memiliki fasilitas yang dapat membuat belajar lebih menarik, visual, dan interaktif.

Keuntungan menggunakan digibook berbasis multimedia ini dalam pembelajaran adalah membuat proses pembelajaran lebih menarik, interaktif dan menyenangkan kepada peserta didik. Dengan digibook tersebut maka video pembelajaran dapat terintegrasi di dalam digibook, menjadi satu kesatuan yang tidak terpisahkan. Tampilan dari digibook ini juga sangat bervariasi dan menarik tergantung bagaimana kita mensettingnya. Penggunaan digibook ini bisa menjadi terobosan baru dalam mengimplementasikan proses pembelajaran dengan TIK yang berbasis multimedia, selain dengan powerpoint dan flash 


\subsection{Materi Pembelajaran Tematik}

Sebagai ilmu pengetahuan,Pembelajaran Tematik meliputi proses, sikap, dan produk. Artinya bahwa dalam belajarPembelajaran Tematik memiliki dimensi proses, hasil (produk), pengembangan sikap ilmiah. Ketiganya bersifat saling terkait, sehingga guru dalam melaksanakan proses pembelajaran harus mengandung ketiga dimensi tersebut.

IPA sebagai produk umumnya berupa fakta, konsep teori, hukum. Konsep merupakan produk dari proses ilmiah. Artinya bahwa produk didapatkan dari serangkaian proses ilmiah. Dalam proses ilmiah (pengamatan) akan didapatkan fakta. Dari berbagai fakta yang diperoleh dibuat generalisasi, sehingga terjadilah konsep. Jadi konsep adalah kumpulan stimulus (benda, peristiwa,dll) yang mempunyai ciri sama (Sulistyorini, 2007).

Dari rumusan diatas memiliki makna bahwa untuk mendapatkan produk diharapkan melalui proses, sehingga dalam pembelajaranPembelajaran Tematik guru dituntut untuk dapat mengajak anak didiknya memanfaatkan alam sekitar sebagai sumber belajar dalam mendapatkan fakta yang akan digeneralisasikan menjadi konsep. JadiPembelajaran Tematik sebagai proses adalah proses untuk mendapatkanPembelajaran Tematik yang dilakukan melalui metode ilmiah. Pada anak-anak SD/MI, metode ilmiah dikembangkan secara bertahap, berkesinambungan, dengan harapan bahwa pada akhirnya akan terbentuk paduan yang lebih utuh sehingga harapannya anak-anak SD/MI mampu melakukan penelitian secara sederhana.

\section{METODE PENELITIAN}

\subsection{Pendekatan dan Jenis Penelitian}

Penelitian ini pada dasarnya merupakan penelitian untuk mengembangkan bagaimana sumber belajar yang berupa buku itu bisa dikemas dalam bentuk multimedia atau disebut dengan digital book (digibook). Oleh sebab itu metode yang digunakan dalam penelitian ini adalah penelitian 4D (four-D Models)s dengan pendekatan kualitatif (Creswell, 2016). Pendekatan kualitatif ini dilakukan pada saat (1) Eksplorasi terhadap sejauhmana pemahaman guru tentang digibook (2) Proses identifikasi tentang sumber belajar yang selama ini digunakan sebagai dasar model yang dapat dikembangkan untuk pembelajaran di sekolah SD terutama pada Pembelajaran Tematik.

Pada tataran pemahaman (verstehen) dilakukan pada proses pemaknaan dalam pencarian model digibook secara interdisipliner antara revitalisasi sumber belajar terhadap perkembangan teknologi sebagai langkah akademis dalam rangka membangun struktur dan kultur guru era baru untuk pembelajaran dalam dunia pendidikan. Penelitian diawali dengan kegiatan lapang, yaitu dengan melakukan observasi langsung tentang hal yang berkaitan dengan potret guru dalam mengajar di Malang yang dilihat dari aspek sumber belajar yang digunakan seperti buku, media dan lainnya. Kajian untuk mengungkap lebih dalam tentang pemahaman guru terhadap digibook di lingkungan sekolah akan dilakukan indepth interview termasuk di dalamnya dengan key informan, Participatory Rural Appraisal (PRA) dan Focus Group Discussion (FGD), hasilnya digunakan sebagai bahan dalam mengembangkan digibook sampai uji coba model sumber belajar ini. 


\subsection{Lokasi Penelitian}

Lokasi penelitian secara purposif yaitu dipilih dengan sengaja karena sesuai dengan penelitian yaitu di Malang sebagai kota pendidikan, kota pariwisata dan kota industry, yang telah secara konsisten melaksanakan program Pendidikan. Pemilihan sekolah juga dilakukan secara purposive, yaitu dipilih 1 SD yang secara kapability mampu secara praktis melaksanakan pendidikan dengan menggunakan digibook, yaitu SDN Sumbersari II.

\subsection{Teknik Pengumpulan data}

Teknik pengumpulan data dalam penelitian ini menggunakan 4 metode dimana metode tersebut digunakan secara simultan dan saling melengkapi satu sama lain. Adapun metode yang digunakan adalah sebagai berikut:

a. FGD yaitu kegiatan curah pendapat atau diskusi bersama antara pihak peneliti dengan para guru kelas 5 yang dijadikan sampel dalam penelitian ini. Hal ini untuk mengetahui persepsi guru di sekolah dasar tentang kemanfaatan digibook dalam mengelola pembelajaran SD

b. Angket, angket ini digunakan untuk mengetahui respon guru maupun siswa ketika proses pembelajaran digunakan dengan memanfaatkan digibook.

c. Observasi, digunakan untuk menganalisis peningkatan kompetensi guru di sekolah dasari dalam mengelola pembelajaran untuk anak SD setelah dilatih dengan menggunakan digibook yang dikembangkan.

d. Dokumentasi, digunakan untuk melengkapi hasil observasi maupun FGD berupa deskripsi kompetensi guru di sekolah dasari dalam mengelola pembelajaran untuk anak SD setelah dilatih dengan menggunakan digibook yang dikembangkan.

\subsection{Instrumen Penelitian}

Instrumen dalam penelitian ini sesuai dengan teknik yang telah digunakan yaitu (1) Panduan FGD, berisi tentang kisi-kisi pertanyaan tentang persepsi guru di sekolah dasar tentang kemanfaatan digibook dalam mengelola pembelajaran SD, (2) Angket, berisi tentang aspek respon siswa maupun guru ketika menggunakan digibook, (3) lembar observasi, berisi tentang deskripsi peningkatan kompetensi guru di sekolah dasari dalam mengelola pembelajaran untuk anak SD setelah dilatih dengan menggunakan digibook yang dikembangkan.

\subsection{Teknik Analisa Data}

\section{Teknik Analisis Data Kualitatif}

Analisis dalam penelitian kualitatif dilakukan sejak sebelum memasuki lapangan, selama di lapangan, setelah di lapangan, dan berlangsung sampai ditemukan Digibook Pada Materi Pembelajaran Tematik . Data yang diperoleh kemudian dikumpulkan untuk diolah secara sistematis. Dimulai dari wawancara, observasi, FGD, mengedit, mengklasifikasi, mereduksi, selanjutnya aktivitas penyajian data serta menyimpulkan data. Teknis analisis data dalam penelitian ini menggunakan model analisis interaktif.

2. Teknik Analisis Data untuk Pengembangan Digibook (Model 4 D) 
Setelah dikembangkannya Digibook, maka harus divalidasi atau diuji coba keefektifannnya, yaitu dengan menguji apakah digibook tersebut dapat diterapkan di sekolah dengan mengunakan penelitian tindakan. Subjek uji coba terbatas dalam hal ini adalah SDN Sumbersari II.

\section{HASIL DAN PEMBAHASAN}

\section{A. Hasil Penelitian}

Penelitian pengembangan ini dilakukan untuk menghasilkan sebuah produk yang berbentuk digital Book (Digibook) pada mata pelajaranPembelajaran Tematik sebagai upaya peningkatan kompetensi guru dalam melakukan pembelajaran di SD. Pada penelitian ini menggunakan beberapa tahapan proses pengembangan produk model $4 \mathrm{D}$. Adapun langkah tersebut adalah sebagai berikut:

\section{Need Assesment (Analisis Kebutuhan)}

Berdasarkan hasil wawancara dan observasi kepada guru kelas IV di SDN Sumbersari II diperoleh informasi awal data yang menyatakan tentang kondisi proses pembelajaran di sana dan kebutuhan siswa. Adapun hasilnya dapat dilihat pada tabel berikut ini:

Tabel 1 Hasil Analisis Kebutuhan di SDN Sumbersari 02 Kota Malang Melalui Hasil Wawancara

\begin{tabular}{lll}
\hline No & Pertanyaan & Temuan \\
\hline
\end{tabular}

Siswa

1 Jumlah dan karakteristik siswa kelas IV Jumlah siswa 22 anak, dan karakteristiknya bermacam-macam baik dari segi kemampuan, gender, latar belakang maupun minat siswa. Bahkan disana ada 4 siswa yang $\mathrm{ABK}$

2 Aktivitas siswa dalam Pembelajaran Aktivitas siswa tergolong sedang, Tematik dan rata-rata kemampuan siswa artinya ada yang dominan aktif tetapi ada pula yang masih ditunjuk oleh guru.

3 Buku yang digunakan siswa dalam Buku Tematik dari Pemerintah proses pembelajaran selama ini

4 Minat siswa dalam penggunaan buku Sejauh ini minat siswa masih cukup, tematik yang digunakan namun jika terlalu lama untuk membaca terkadang anak jadi malas dan bosan

$5 \quad$ Kemampuan siswa memahami materi ketika menggunakan buku tersebut Siswa yang dominan dan yang gemar membaca buku sangat aktif akan tetapi yang tidak terbiasa membaca ditanya guru tentang materi yang ada mudah lupa dan sulit untuk dipahami 


\section{Guru}

1 Kemampuan guru dalam mengajar Kemampuan guru sudah bagus materi menggunakan buku tematik yang ada dibuku dapat tersampaikan semuanya

2 Kendala yang dihadapi saat penggunaaan Guru terkadang merasa bahwa anakbuku tematik tersebut yang digunakan anak sulit untuk dikondisikan ketika disuruh membaca buku, mereka tidak fokus bahkan ada yang tidak mendengarkan perintah guru, ngobrol dengan teman sebangku atau dengan sebelahnya

3 Upaya yang telah dilakukan guru dalam melakukan proses pembelajaran

Guru memakai trik dengan Yel-yel supaya anak memperhatikan dan diam mendengarkan intruksi guru, tetapi itu tidak berlangsung lama, beberapa menit kemudian anak-anak ramai lagi

$4 \quad$ Harapan guru kelas IV ketika mengajar Pembelajaran Tematik

Guru berharap bisa menciptakan pembelajaran yang bisa menarik bagi siswa, dan mereka mudah memahami materi tidak sekedar menghafal

Berdasarkan hasil dari kegiatan wawancara analisis kebutuhan yang dilakukan diatas, dapat disimpulkan bahwa guru dalam mengajar Pembelajaran Tematik selama ini dengan menggunakan buku yang diberikan pemerintah belum berjalan maksimal dan masih ditemukan beberapa kendala. Apalagi dihadapkan pada kondisi siswa disana yang tidak hanya anak-anak reguler tetapi terdapat pula anak ABK. Kemampuan dalam pemahaman materi juga terkategori belum sepenuhnya diterima siswa dengan baik, hanya beberapa siswa saja dominan yang memang tergolong aktif dan pintar. Rata-rata minat siswa saat menggunakan buku tematik tersebut terkadang naik-turun dimungkinkan karena bahan ajar tersebut kurang menarik, maka dari itu dibutuhkan bahan ajar yang mampu memahamkan siswa pada materi dengan baik dan juga membangkitkan motivasi siswa.

Tabel 2 Hasil Analisis Kebutuhan di SDN Sumbersari 02 Kota Malang Melalui Hasil Observasi

\begin{tabular}{|c|c|c|c|}
\hline No & Aspek pengamatan & $\mathrm{Ya}$ & Tidak \\
\hline 1 & $\begin{array}{l}\text { Kurikulum pembelajaran yang diterapkan di SD adalah } \\
\text { Kurikulum } 2013\end{array}$ & $\mathrm{v}$ & \\
\hline 2 & Ketersediann buku di sekolah cukup memadai & $\mathrm{v}$ & \\
\hline 3 & $\begin{array}{l}\text { Siswa memiliki antusias yang tinggi terhadap proses } \\
\text { Pembelajaran Tematik yang diterapkan guru }\end{array}$ & & $\mathrm{v}$ \\
\hline 4 & $\begin{array}{l}\text { Pembelajaran Tematik yang diterapkan menggunakan } \\
\text { langkah-langkah saintifik }\end{array}$ & $\mathrm{v}$ & \\
\hline 5 & $\begin{array}{l}\text { Buku tematik yang dipakai guru dapat mengaktifkan siswa } \\
\text { dalam pembelajaran }\end{array}$ & & $\mathrm{v}$ \\
\hline
\end{tabular}




\begin{tabular}{lll}
\hline 6 & Buku tematik memudahkan siswa dalam memahami materi & $\mathrm{v}$ \\
7 & Buku tematik mampu membuat siswa menjadi kreatif & $\mathrm{V}$ \\
8 & $\begin{array}{l}\text { Buku tematik membantu membangkitkan interaksi siswa } \\
\text { dengan siswa yang lainnya dan antara siswa dengan guru }\end{array}$ & $\mathrm{V}$ \\
10 & Semua siswa mengikuti proses Pembelajaran Tematik & $\mathrm{V}$ \\
\hline
\end{tabular}

Berdasarkan hasil observasi diatas menunjukkan bahwa Pembelajaran Tematik selama ini yang diterapkan di SDN Sumbersari 02 Malang belum sepenuhnya berjalan optimal. Hal ini terlihat dari beberapa indikator yaitu buku tematik yang tersedia di sekolah dari sisi jumlah sudah cukup memadai namun antusias siswa terhadap Pembelajaran Tematik masih kurang. Siswa ketika diajar guru sebagian yang tidak memperhatikan, mereka memilih mengobrol dengan teman sebangku bahkan ada yang membawa mainan dari rumah. 1-2 siswa terlihat ketika diajar kepala diletakkan di bangku, hal ini sering dilakukan ketika proses pembelajaran.

Di langkah pembelajaran guru sudah berusaha menerapkan langkah-lankah saintifik, namun siswa dalam belajar kurang kreatif dan kurang membangkitkan interaksi siswa dan guru. Ada 2 orang terlihat dominan sangat aktif dan kreatif. Hal ini diperkuat dari hasil FGD bahwa anak-anak ketika menggunakan buku siswa terkesan masih menghafal, budaya membaca dari siswa juga nampak kurang.

\section{Design (Perencanaan)}

Pada tahap kedua ini dilakukan perencanaan dengan menentukan produk yang akan dikembangkan yaitu digital buku (digibook) dengan langkah pertama yaitu menentukan tema dan subtema yang sesuai jika digunakan untuk Pembelajaran Tematik, dengan memilih subjek uji coba produk pada siswa kelas IV pada saat Pembelajaran Tematik berlangsung. Setelah itu menetapkan kompetensi dasar, indikator dan tujuan pembelajaran. Dalam merencanakan pengembangan digibook ini hanya dikembangkan pada pembelajaran ke 1

Langkah berikutnya yaitu pengembangan produk awal yang merupakan pembuatan produk sebelum dilakukannya proses validasi kepada ahli bahan ajar, ahli materi dan ahli pembelajaran. Pada tahap ini merupakan tahap penting yaitu bagaimana cara menyusun sistematika digibook yang benar. Dimulai dari merancang sampul kemudian menentukan materi sesuai tema yang dipilih. Berikut ini tahapan dalam pembuatan produk awal:
a. Pembuatan sampul
b. Pemetaan KD, indikator dan tujuan Indikator
c. Halaman kata pengantar dan hak cipta
d. Halaman awal materi pengantar
e. Contoh materi
f. Materi berisi video
g. Materi berisi tugas/praktik
h. Materi berisi aktivitas atau tugas/praktik
i. Cover belakang

\section{Develoop (Pengembangan)}

Pada tahap pengembangan ini dilakukan proses validasi. Validasi dilakukan untuk 
menguji kevalidan atau kelayakan produk yang dikembangkan. Baik dari segi tampilan, materi, kesesuaian dengan model dan lain sebagainya yag menyangkut syarat pembuatan digibook. Validasi dilakukan oleh beberapa validator yang merupakan ahli dalam bidang bahan ajar beruba digibook ini.

Proses validasi dilakukan dalam dua kali tahapan, sehingga dalam penelitian ini akan ada jenis datayang diperoleh yaitu validasi pertama dimana validasi dilakukan setelah dikembangkannya produk dan validasi kedua yaitu validasi yang dilakukan setelah melakukan revisiproduk yang dilakukan atas kritik dan saran sertapenilaian angket. Berikut ini paparan tentang hasil validasi:

\section{a. Validasi Ahli Bahan Ajar Digibook}

Validasi tahap I ini dilakukan dengan menetukan validator ahli bahan ajar berupa digibook yaitu bapak Ari Dwi Haryono, M.Pd. Validasi digibook dinilai dengan beberapa aspek penilaian yaitu: komponen digibook, Kesesuaian Kegiatan, Kejelasan Petunjuk, Anatomi dan kesesuaian digibook dengan materi. Adapun hasil yang diperoleh dari validasi ini adalah sebagai berikut:

1) Validasi bahan ajar tahap I

Setelah pembuatan produk awal selesai, diperoleh masukan dari validator yaitu materi masih belum terstruktur dan ada kegiatan yang tidak saling berhubungan, panduan kerja masih belum terlihat, materi perlu disesuaikan lagi dengan tema dan subtema yang dipilih, Layout perlu buat semenarik mungkin. Hasil validasi digibook tahap I dapat dilihat pada tabel berikut:

\section{Tabel 3 Rekapitulasi Angket Validasi Ahli Bahan Ajar Tahap I}

\begin{tabular}{llc}
\hline No & \multicolumn{1}{c}{ Aspek Penilaian } & $\begin{array}{c}\text { Hasil } \\
\text { Validasi }\end{array}$ \\
\hline 1 & Digibook yang dikembangkan memuat petunjuk belajar & 3 \\
2 & Memuat kompetensi Dasar dan indikator yang berlaku & 4 \\
3 & Mencantumkan tujuan pembelajaran & 4 \\
4 & Materi sesuai tema dan subtema yang dikembangkan & 4 \\
5 & Bahasa yang digunakan sesuai dengan usia siswa & 3 \\
6 & Bahasa yang digunakan komunikatif & 3 \\
7 & Tampilan tek/font dapat dibaca dengan jelas & 2 \\
8 & Desain dampat menarik perhatian siswa & 4 \\
9 & Adanya gambar yang mendukung proses penyerapan materi & 3 \\
10 & Terapat video yang bersifat interaktif & 3 \\
12 & Terdapat latihan soal yang bersifat menantang & 2 \\
& Skor Total & 32 \\
& Skor Maksimal & 48 \\
& Presentase & $66,7 \%$ \\
\hline
\end{tabular}

Hasil validasi seperti terttuang pada tabel diatas diperoleh skor 32 atau 66,7\%. Hal ini menunjukkan bahwa digibook yang dikembangkan sudah layak namun masih banyak 
dilakukan revisi atatu perbaikan. Adapun hasil masukannya adalah jenis dan ukuran huruf yang digunakan sesuai tingkat anak SD, soal lebih dibuat menantang tidak hanya soal rutin, Gambar dan video yang ditampilkan tidak hanya sekedar melengkapi isi dari buku tersebut tetapi lebih disesuaikan dengan materi.

\section{2) Validasi bahan ajar tahap II}

Berdasarkan penilaian dan kritik saran dari ahli bahan ajar terhadap digibook ini maka dapat dilakukan proses revisi produk dengan saran yang telah diberikan oleh validator. Adapun hasil validasi ini sebagai berikut:

\section{Tabel 4 Rekapitulasi Angket Validasi Ahli Bahan Ajar Tahap I}

\begin{tabular}{llc}
\hline No & \multicolumn{1}{c}{ Aspek Penilaian } & $\begin{array}{c}\text { Hasil } \\
\text { Validasi }\end{array}$ \\
\hline 1 & Digibook yang dikembangkan memuat petunjuk belajar & 3 \\
2 & Memuat kompetensi Dasar dan indikator yang berlaku & 4 \\
3 & Mencantumkan tujuan pembelajaran & 4 \\
4 & Materi sesuai tema dan subtema yang dikembangkan & 4 \\
5 & Bahasa yang digunakan sesuai dengan usia siswa & 3 \\
6 & Bahasa yang digunakan komunikatif & 3 \\
7 & Tampilan tek/font dapat dibaca dengan jelas & 4 \\
8 & Desain dampat menarik perhatian siswa & 4 \\
9 & Adanya gambar yang mendukung proses penyerapan materi & 4 \\
10 & Terapat video yang bersifat interaktif & 4 \\
12 & Terdapat latihan soal yang bersifat menantang & 3 \\
& Skor Total & 44 \\
& Skor Maksimal & 48 \\
& Presentase & $91,6 \%$ \\
\hline
\end{tabular}

Berdasarkan hasil data diatas menunjukkan bahwa bahan ajar digibook pada validasi tahap II diperoleh skor 91,6\% maka buku ini dapat dikatakan layak untuk dipakai. Menutut ahli buku ajar ini dikatakan bahwa digibook yang dikembangkan dari sisi komponen sudah memuat petunjuk yang jelas, sesuai dengan $\mathrm{KD}$, terdapat keelasan tujuan yang hendak dicapai, kegiatan sudah sesuai dengan tingkat usia anak, bahasa yang digunakan sudah tepat. Desain menarik siswa, gambar dan video sangat mendukung.

\section{b. Validasi Ahli Materi Digibook}

Validasi bahan ajar terhadap ahli materi dilakukan dengan tujuan mengetahui tingkat kelayakan suatu materi yang diberikan dalam Buku digital ini. Materi yang dikembangkan didalam buku ini adalah Pembelajaran Tematik. Validasi bahan ajar berupa digibook dinilai dari beberapa aspek yaitu: kesesuaian tujuan, kelayakan isi, kelayakan bahasa. Adapun hasil yang diperoleh adalaha sebagai berikut: 


\begin{tabular}{|c|c|c|}
\hline No & Aspek Penilaian & $\begin{array}{c}\text { Hasil } \\
\text { Validasi }\end{array}$ \\
\hline & Kesesuaian Tujuan & \\
\hline 1 & Materi yang disajikan sudah sesuai dengan dengan KD & 4 \\
\hline 2 & Materi yang disajikan telah sesuai dengan indikator yang ada & 3 \\
\hline \multirow[t]{2}{*}{3} & Indikator dalam mengemas materi pembelajaran terlihat jelas & 3 \\
\hline & Kelayakan isi & \\
\hline 1 & Materi telah mendukung adanya KD yang ada & 3 \\
\hline 2 & Materi telah mendukung adanya indikator yang ada & 3 \\
\hline 3 & Materi dalam digibook memberikan konsep yang benar & 3 \\
\hline 4 & Keterkaitan antar mata pelajaran tak terlihat & 3 \\
\hline 5 & $\begin{array}{l}\text { Materi yang diberikan dekat dengan kehidupan sehari-hari } \\
\text { anak }\end{array}$ & 3 \\
\hline \multirow[t]{2}{*}{6} & Jumlah latihan cukup dan sesuai materi & 3 \\
\hline & Kelayakan bahasa dan tulisan & \\
\hline 1 & Penggunaan bahasa dalam bukutelah sesuai EYD & 3 \\
\hline 2 & Bahasa yang digunakan sangat mudah dipahami & 4 \\
\hline 3 & Menggunakan bahasa yang interaktif terhadap siswa & 3 \\
\hline \multirow[t]{3}{*}{4} & Penggunaan bahasa sesuai tingkatan/usia siswa & 3 \\
\hline & Skor Total & 41 \\
\hline & Skor Maksimal & $\begin{array}{c}52 \\
78,8 \%\end{array}$ \\
\hline
\end{tabular}

Berdasarkan penilaian dari ahli materi diperoleh presentase sebesar 78,8\%, maka dapat dikategorikan bahan ajar Digibook layak digunakan. Hasil validasi ini merupakanhasil revisi pada tahap validasi I. Meskipun dilihat dari skor yang diberikan masih ada beberapa point yang perlu ditingkatkan dengan cara merevisi. Angket validasi terhadap bahan ajar untuk menilai digibook ini memiliki saran yaitu dari kelayakan isi dimana perlu menyesuaikan $\mathrm{KD}$ dan indikator yang diintegrasikan dalam tema tempat tinggalku, keterkaitan antar mata pelajaran masih bisa disinergikan dan contoh soal yang dibuat bisa merangsang pikiran anak untuk lebih tertantang.

\section{c. Uji Coba}

Uji coba dilakukan setelah proses validasi selesai. Ini pada tanggal 13 Juni 2017 di SDN Sumbersari 02 Kota Malang. Subjek Ujicoba adalah siswa kelas IV dengan jumlah siswa 21. Pada saat uji coba guru berperan sebagai guru model yang mengajar dengan menggunakan digibook. Uji coba ini skala kecil ini dilakukan untuk mengetahui sejauh mana guru mampu menggunakanbuku digibook dan dari siswa bagaimana mereka memahami materi. 
Dari hasil ujicoba diperoleh data yang bersumber dari pengamatan, hasil angket siswa dan guru. Pada saat uji coba kelompok kecil ini diperoleh data sebagai berikut:

Tabel 5 Rekapitulasi Angket Respon Siswa dalam Penggunaan Digibook

\begin{tabular}{|c|c|c|c|c|c|}
\hline No & Aspek Penilaian & TS & KS & $\mathrm{S}$ & SS \\
\hline 1 & $\begin{array}{l}\text { Kemudahan Memahami Materi belajar } \\
\text { menggunakan digibook }\end{array}$ & 0 & 5 & 10 & 6 \\
\hline 2 & $\begin{array}{l}\text { Siswa tidak mengalami kesulitan dalam } \\
\text { penggunaan digibook }\end{array}$ & 0 & 7 & 9 & 5 \\
\hline 3 & $\begin{array}{l}\text { Tulisan atau teks yang ada di digibook mudah } \\
\text { terbaca }\end{array}$ & 0 & 3 & 11 & 7 \\
\hline 4 & Soal yang ada mudah untuk dikerjakan & 0 & 4 & 11 & 6 \\
\hline 5 & $\begin{array}{l}\text { Anak-anak merasa senang ketika belajar } \\
\text { menggunkan digibook }\end{array}$ & & 5 & 6 & 10 \\
\hline 6 & $\begin{array}{l}\text { Anak-anak penasaran ketika melihat tampilan } \\
\text { digibook }\end{array}$ & 1 & 3 & 12 & 5 \\
\hline 7 & $\begin{array}{l}\text { Siswa merasa semangat belajar ketika } \\
\text { menggunakan digibook }\end{array}$ & 0 & 5 & 11 & 5 \\
\hline 8 & $\begin{array}{l}\text { Anak-anak ingin belajar terus menggunakan } \\
\text { digibook meskipun jam belajar sudah berakhir }\end{array}$ & 0 & 11 & 5 & 6 \\
\hline 9 & $\begin{array}{l}\text { Siswa mudah mengingat materi ketika guru } \\
\text { menggunakan media digibook }\end{array}$ & 0 & 7 & 10 & 4 \\
\hline 10 & Siswa mengantuk ketika menggunakan di gibook & 14 & 4 & 2 & 1 \\
\hline 11 & Siswa bosan belajar menggunakan digibook & 14 & 7 & 0 & 0 \\
\hline 12 & Siswa merasa rugi belajar menggunakan digibook & 12 & 9 & 0 & 0 \\
\hline 13 & $\begin{array}{l}\text { Siswa aktif memperhatikan penjelasan guru } \\
\text { dalam pelajaran }\end{array}$ & 1 & 5 & 7 & 8 \\
\hline \multirow[t]{4}{*}{14} & $\begin{array}{l}\text { Pembelajaran lebih menraik karena menggunakan } \\
\text { digibook }\end{array}$ & 1 & 6 & 11 & 3 \\
\hline & Jumlah skor & & 208 & & \\
\hline & Skor Maksimal & & 294 & & \\
\hline & Presentase & & $70,7 \%$ & & \\
\hline
\end{tabular}

Berdasarkan tabel diatas terlihat bahwa respon siswa ketika menggunakan digibook dalam kategori baik. Hasil rekapitulasi menunjukkan bahwa 70,7\% siswa memiliki respon positif. Hini terlihat dari beberapa indikator bahwa rata-rata dari setiap aspek penilaian 1618 siswa dari jumlah 21 siswa merasa bahwa dalam belajar menggunakan digibook mereka tidak mengalami kesulitan, tulisan yang ada pada teks menurut mereka mudah terbaca, siswa sangat penasaran ketika diajar dengan digibook, terlihat semangat belajar mereka juga sangat tinggi. Hasil angket ini juga didukung oleh hasil observasi melalui rekaman foto bahwa siswa sangat ceria, guru dapat membawa proses pembelajaran dengan santai, sesekali guru mengajak siswa untuk bercanda, dan di angket ketidakbosanan mereka ditunjukkan dari 21 orang yang tidak merasa ngantuk atau merasa rugi belajar adalah 14 siswa. 
Pada tahap pembelajaran ini juga, siswa diminta untuk mengamati video pembelajaran, kemudian guru memberikan pertanyaan yang menantang bagi siswa, Nampak bahwa siswa sangat senang sekali mereka tidak merasa mengantuk atau bosan. Hal ini juga disampaikan beberapa siswa mereka lebih senang langsung melihat dalam video daripada disuruh membaca buku. Ini menunjukkan bahwa gaya belajar anak-anak adalah secara visualisasi. Proses pembelajaran dengan mengamati video nampak pada gambar dibawah ini:

\section{B. Pembahasan}

Dari hasil penelitian pengembangan ini diperoleh banyak temuan dari lapang yaitu tentang proses pembelajaranPembelajaran Tematik dengan menggunakan digibook. Menurut penelitian ini ketika dilakukan validasi terhadap ahli bahan ajar dengan persentase ...yang menandakan bahwa bahan ajar ini layak digunakan dan sangat valid jika berdasar padapembuatan komponen buku. Hal tersebut sesuai dengan proses dan langkah menurut teori dikans (2004:24) yang dikatakan bahwa dalam pembuatan buku ajar ini ada beberapa langkah yaitu dari komponen desain, daftar isi, kegiatan belajar siswa, konsep materi benar, rangkuman materi, percobaan dan pelaporan.

Pada saat proses pembelajaran ddengan menggunakan digibook ditemukan bahwa siswa sangat kondusif saat melakukan pengamatan, keaktifan cukup terjalin sehingga aktivitas siswa nampak optimal.. Berdasarkan hasil penelitian ini dapat disimpulkan bahwa penggunaan digital book mempengaruhi aktivitas dan minat siswa. Hal tersebut sesuai dengan penrnyataan Rusman (2012:323) bahwa pembelajaran akan lebih bermakna jika siswa diberi kesempatan untuk berpartisipasi dalam berbagai aktivitas kegiatan pembelajaran, sehingga siswa mampu mengaktualisasikan kemampuannya didalam dan diluar kelas.

Hasil dilapang ditemukan bahwa dari semua siswa yang melakukan proses pembelajaran ditemukan adanya siswa yang malas dan tidak memperhatikan proses pembelajaran. Siswa ini merupakan anak berkebutuhan khusus. Ia juga terlihat sering menyendiri dan kurang aktif berkomunikasi dengan teman sekelasnya. Dengan kondisi demikian perhatian orang tua juga dirasa kurang. Hal ini menyebabkan kurangnya motivasi belajar siswa tersebut. Sesuai dengan pendapat Skinner (Sunarto \& Hartono, 2013:19) yang menjelaskan bahwa motivasi belajar sangat ditentukan oleh lingkungan keluarga. Untuk mewujudkan suasana belajar yang menyenangkan bagi anak, orang tua harus mampu menciptakan keadaan yang harmonis serta waktu yang cukup untuk memberi perhatian kepada anak. Sebaliknya, jika hubungan dalam keluarga tidak harmonis dan waktu yang diberikan kepada anak berkurang, hal tersebut akan berdampak pada turunnya motivasi untuk belajar dan mengakibatkan hasil belajarnya yang rendah.

\section{SIMPULAN DAN SARAN}

\section{Simpulan}

Pada penelitian pengembangan Buku Digital (Digibook) ini kesimpulan bahwa :

a. Hasil penelitian yang diperoleh yakni nilai validitas bahan ajar bernilai 91,6\%,begitu juga pada tahap uji validasi ahli materi mendapat skor $78,8 \%$, semua dalam kriteria valid. 
b. Mengenai keefektifan bahan ajar ditunjukkan dari respon positif yang diperoleh dari guru dan siswa sebagai pengguna produk. Setelah dilakukan revisi bahan ajar, nilai efektifitas bahan ajar pada tahap uji diperoleh hasil 70,7\%, ini dalam kriteria efektif. Guru dan siswa menyimpulkan bahwa bahan ajar berupa Digibook efektif digunakan dalam pembelajaran

\section{Saran}

Dalam penelitian pengembangan ini memiliki beberapa kelemahan yang perlu diperhatikan, diantaranya Bahan ajar Digibook hanya untuk siswa yang memiliki intelegensi normal dan tinggi sehingga tidak sesuai jika diaplikasikan untuk kelas inklusi maka dari itu disarankan agar peneliti selanjutnya mengembangkan Digibook untuk siswa baik yang normal maupun berkebutuhan khusus.

\section{DAFTAR PUSTAKA}

Depdiknas. 2001. Peningkatan Mutu Pendidikan Di Sekolah Dasar. Jakarta.

Djaman Satori dkk, E. 2003. Profesi Keguruan I. Universitas Terbuka.

Creswell, John W. 2016.Research Design, pendekatan Kualitatif, Kuantitatif, dan Mixed. Yogyakarta: Pustaka Pelajar.

Mulyana, E. 2007. Menjadi Guru Profesional (mencipatakan Pembelajaran Kreatif dan Menyenangkan). Bandung. PT. Remaja Rosdakarya.

Sugiyono. 2013. Metode Penelitian Pendidikan, Pendekatan Kuantitatif, Kualitatif, dan R\&D. Bandung: Alfabeta

Sulistyorini,Sri. 2007. Model PembelajaranPembelajaran Tematik Sekolah Dasar dan Penerapannya Dalam KTSP. Semarang: Tiara Wacana

Sunarto \& Hartono. 2013. Perkembangan Peserta Didik.Jakarta:Rineka Cipta 